\title{
EFFECTS OF SHOTI (CURCUMA ZEDOARIA) ON GROWTH PERFORMANCES AND HEMATO-BIOCHEMICAL PARAMETERS OF BROILER CHICKS
}

\author{
M. J. Alam, M. S. Islam ${ }^{2 *}$, M. M. Rahman ${ }^{2}$, S. Mazumder ${ }^{1}$ and N. Ahmad ${ }^{1}$ \\ ${ }^{1}$ Department of Physiology, Bangladesh Agricultural University, Mymensingh-2202, Bangladesh; ${ }^{2}$ Department \\ of Physiology \& Pharmacology, Bangabandhu Sheikh Mujibur Rahman Agricultural University, Gazipur-1706, \\ Bangladesh
}

\begin{abstract}
The research was conducted to observe the effect of shoti meal on weight gain and some selected hematological values such as total erythrocyte count (TEC), hemoglobin ( $\mathrm{Hb}$ ) and erythrocyte sedimentation rate (ESR) and biochemical parameters such as aspartate transaminase (AST), alanine transaminase (ALT), uric acid and creatinine in broilers. Fresh rhizomes were washed, minced and dried and pulverized in a flour meal. A total of 20 broilers ( 16 day old) were randomly divided into four equal groups. Group A was treated as control and groups B, C and D were fed with 5\%,10\% and 15\% shoti respectively for 22 days. The result showed that body weight of broilers fed 10\% shoti meal (group C) was higher than that of other treated groups. After having completed the feeding trial, birds were sacrificed to collect blood samples for hematological and serum biochemical analysis. Total erythrocyte count $($ TEC) in group D varied significantly $(\mathrm{p}<0.05)$ from all other groups. The highest hemoglobin content was recorded in group B and lowest in group A (Control). Significant $(\mathrm{p}<0.05)$ differences were observed among the groups compared to control group. The highest erythrocyte sedimentation rate (ESR) was in group B and lowest was in group A (control) and group C (shoti 10\%). Serum AST within the treated groups 15\% shoti, (Group D) was significantly $(\mathrm{p}<0.05)$ higher to that of $5 \%$ shoti (Group B), and $10 \%$ shoti (group C). The ALT value in group A was significantly higher $(\mathrm{p}<0.05)$ than the other groups. Uric acid concentration within the treated groups, group $\mathrm{C}(10 \%$ shoti $)$ showed significantly higher $(\mathrm{p}<0.05)$ than the group B $(5 \%$ shoti) and group D $(15 \%$ shoti). Creatinine concentration decreased significantly $(\mathrm{P}<0.05)$ in control (group A) to that of others group. Biochemical parameters analyzed in present research is the first report in broilers.
\end{abstract}

Keywords: Curcuma zedeoria, shoti, broiler hemato-biochemical

\section{INTRODUCTION}

Curcuma zedoaria is locally known as shoti or wheet that is a starchy rhizomatous or tuberous form of the Zingiberaceae family, commonly known as ginger family. It is able to grow up to one and half meters or even more. The leaves are around $80 \mathrm{~cm}$ long and they usually have a purple-brown flush along the midrib on both surfaces of the leaf. The chemical composition of shoti meal is found to be low in protein, fat, trace minerals and therefore mainly as a source of energy. Curcuma spp. contains turmerin (a water-soluble peptide), essential oils (such as turmerones, atlantones and zingiberene) and curcuminoids including Curcumin with the formula: [1,7bis-(4-hydroxy-3-methoxyphenyl)-1,6-heptadiene-3,5- dione] and the curcuminoids can be defined as phenolic compounds derived from the roots of Curcuma spp. Curcumin (diferuloylmethane) which is also called the Indian saffron is a low molecular weight polyphenol, first isolated almost two centuries ago (Aggarwal et al., 2007 ). It has been reported that curcuminoids exist in some Zingiberaceae species such as Curcuma zedoaria (white turmeric), Curcuma longa (turmeric), Curcuma mangga (manogo ginger), Curcuma aromatica (wild turmeric), Curcuma xanthorrhiza (ubat maaju), Costus speciosus (crepe ginger), Zingiber cassumunar (cassumunar ginger) Etlingera elatior (torch ginger) and Curcuma Phaeocaulis (Aggarwal et al., 2007). Five compounds were isolated from $C$. xanthorrhiza, the hexane extract afforded three pure compounds, which were identified as $\alpha$ - curcumene, germacrone and zederone, while dichloromethane extract gave yellow powder product, which was characterized as curcumin together with colourless oil, xanthorrhizol. The studies on $C$. heyneana afforded four compounds, the hexane extract yielded oxycurcumenol epoxide, which is a new natural product, isocurcumenol and curcumenol. In addition, dichloromethane extract produced stigmasterol. The following biological activities; larvicidal, cytotoxicity and antimicrobial activities carried out on these

*Corresponding e-mail address: shahidulvet07@yahoo.com 
plants have not been reported previously. However the antioxidant activity has been reported by Rashid and Yuhasliza (2004). The results of bioactivity tests revealed that some of the plant crude extracts showed strong biological activities (Rashid and Yuhasliza, 2004). Nevertheless, most of the isolated pure compounds showed only weak to moderate activity. Larvicidal test results both on the plants crude extracts showed that non crude extracts exhibited high toxicity with a LC50 value between $26.4 \mu \mathrm{g} / \mathrm{ml}$ and $34.9 \mu \mathrm{g} / \mathrm{ml}$. On the other hand, curcumin and curcumenol showed antimicrobial activity against Staphylococcus aureus and Pseudomonas aeruginosa. The results obtained for antioxidant activity test revealed that curcumin possessed stronger antioxidant activity, while the isolated pure compounds from $C$. heyneana were not active in the assay. Cytotoxicity activity on the isolated pure compounds from $C$. heyneana including oxycurcumenol epoxide, curcumenol and isocurcumenol exhibited moderate cytotoxic activity with LC50 values 11.9, 12.6 and 13.3 $\mu \mathrm{g} / \mathrm{ml}$ respectively, while curcumin showed strongest inhibitory activity with LC50 value $9.1 \mu \mathrm{g} / \mathrm{ml}$ (Rashid and Yuhasliza, 2004). Curcuma zedoaria grows mainly in the East-Asian countries including China, Vietnam, India, Bangladesh, Indonesia, Malaysia and Japan (Islam et al., 2005; Tipthara et al., 2007). Shoti meal generally has adverse effects on apparent digestibility compared with the control diets for broilers. In different countries in the world there is available data on shoti diet in broiler chicks but in Bangladesh there is no available data in this context. Therefore, the proposed work is an attempt to study the effects of shoti based diet on growth performance, hematology and some serum biochemical parameters in broiler chicks. The aim of the research is to examine- the effects of shoti on growth performance of broilers, on hematological parameters (TEC, Hb and ESR) and on serum biochemical parameters as serum aspertate aminotransferase (AST), serum alanine aminotransferase (ALT), uric acid and creatinine

\section{MATERIALS AND METHODS}

\section{Experimental design}

The experiment was conducted in the Department of Physiology of Bangladesh Agricultural University (BAU), Mymensingh, where birds were reared in the poultry rearing facilities of the Department in an ambient environment. Twenty Cobb-500 broilers broiler chicks aging 16 days were collected from local commercial broiler farm and randomly divided into four equal groups. Group A was considered as control and groups B, C and D were considered as treated groups. Shoti meal was prepared at 5\%,10\% and $15 \%$ fed to group B, C and D respectively with feed throughout the experimental period. Body weight of individual bird was recorded at the beginning and at every three day up to the end of experiment for 35 days. The birds were sacrificed to collect blood sample for hematological and biochemical analysis.

\section{Shoti meal preparation}

Curcuma zedoaria (shoti) was collected from BAU campus and sorted on the basis of white color of the rhizome. Then they were washed, chopped into pieces, sun dried and pulverized in a flour meal. The procedure followed was essentially as that was Latif et al. (1979).

\section{Management of the chiks}

The commercial management procedures were followed during the whole experimental period. Fresh and dried rice husk was used as a litter at a depth of $2 \mathrm{~cm}$. The litter was stirred three times in a week to prevent cake formation. Once in the whole experimental period old litter material was changed using new rice husk to prevent fungal or coccidial infection. Each pen was $2.5 \mathrm{ft} \times 2 \mathrm{ft}$ and was allocated for five birds. Therefore, the space given for each bird was 1 square ft. The birds were always exposed to continuous lighting of 12 hours a day. Electric bulbs were used to provide necessary light. In order to maintain required temperature $\left(105^{0} \mathrm{~F}\right)$ and humidity inside the pens, all the windows of the laboratory were kept open during day and during night a 100 watt bulb was provided as a source of heat. One trough feeder and one round waterer were provided for each pen. Feeders were cleaned everyday at morning and afternoon and fresh clean drinking water was supplied for all the times. Proper hygienic and sanitation programs like foot bath of the shed, not to the entrance of wild bird to the shed, apron and gloves use during feeding of the bird etc. were followed during the experimental period. 


\section{Measurement of body weight}

The body of each birds was measured with the help of electric balance on the day 16 of age ( 0 day of experiment) and subsequently at every third days interval up to slaughter.

Total weight gain in $\%=\frac{\text { Averagefinal weight }- \text { Averageinitialweight }}{\text { Averageinitialweight }}$

\section{Collection of blood}

Blood from each bird was collected at slaughter. A number of sterile test tubes containing anticoagulant (3.8\% Trisodium citrate solution) at a ratio of 1:10 were taken. About $5.0 \mathrm{ml}$ of blood was collected for hematological studies. The hematological studies were performed within two hours of collection.

\section{Preparation of serum}

Three $\mathrm{ml}$ of blood was collected from wing veins in the sterile glass test tube. The blood containing tubes were placed in slanting position at room temperature for clotting. Then the tubes were incubated overnight in refrigerator $\left(4^{0} \mathrm{C}\right)$ and the serum was collected. The sample was centrifuged at $1000 \mathrm{rpm}$ for 15 minutes to have a more clear serum. The serum samples were separated and stored at $-20^{\circ} \mathrm{C}$ till analysis. The erythrocyte sedimentation rate (ESR) was determined in a period of one hour using Wintrobe hematocrit tube. The result was expressed in mm/in 1st hour. The hemoglobin content and packed cell volume were determined as per method by Lamberg and Rothstein (1977). The result was expressed in gm percentage (gm \%) and percentage (\%) respectively. AST and ALT measurement was performed using automatic blood analyzer (Stat Fax 3300, Drawen 1679, and Palm City, FL 34991, USA). The result was expressed in U/L. Colorimetric reaction (Jaffe reaction) of creatinine with alkanine picrate measured kinetically at $490 \mathrm{~nm}$ (490-510), without any pretreatment step. This reaction has been improved (specificity, speed, and adaptability) by the development of an initial rate method. Colorimetric reaction of NH3 with salicylate and hypochlorite measured kinetically at $580 \mathrm{~nm}$, without any pretreatment step. This reaction has been improved (specificity, speed and adaptability) by the development of an initial rate method.

\section{Statistical analysis}

A randomized complete block (RCB) design with more than one observation per cell was applied. The data were collected and the Mean \pm SE were calculated by using descriptive statistics. An analysis of variance (ANOVA) table had been constructed with the help of computer package MSTAT for identifying any statistically significant difference among the groups. The mean difference among the treatments was determined as per Duncan's multiple range test (Gomez and Gomez, 1984).

\section{RESULTS AND DISCUSSION}

Experiment was conducted to study the effect of different level of shoti as a source of carbohydrate in broilers. The initial body weight (day 16) was more or less similar (308.33 $\pm 2.33 \mathrm{gm}$ to $316.33 \pm 4.00 \mathrm{gm})$ in all the groups. Body weight increased with advancement of age in all the groups (Table 1). But significantly $(\mathrm{p}<0.05)$ higher weight gain were recorded in group B (5\% shoti) and group C (10\% shoti) on sampling day 38 . A minimum weight gain was recorded in group A (control).

Table 1. Body weight (Mean \pm SE) of different groups of broilers $(n=5)$ after feeding different level of shoti. Values with different letter in a column differ significantly $(\mathrm{p}<0.05)$.

\begin{tabular}{lllll}
\hline \multirow{2}{*}{ Groups } & \multicolumn{2}{c}{ Pre-treatment $(\mathrm{g})$} & \multicolumn{2}{c}{ Post-Treatment $(\mathrm{g})$} \\
\cline { 2 - 5 } & \multicolumn{1}{c}{ Day 16 } & Day 23 & Day 30 & Day 38 \\
\hline Group A (Control) & $308.33 \pm 2.33$ & $720.00 \pm 20.00^{\mathrm{b}}$ & $923.33 \pm 3.33^{\mathrm{d}}$ & $1186.67 \pm 3.00^{\mathrm{d}}$ \\
Group B (5\% shoti) & $316.67 \pm 1.00$ & $716.67 \pm 4.00^{\mathrm{b}}$ & $1116.67 \pm 2.00^{\mathrm{b}}$ & $1316.67 \pm 3.00^{\mathrm{b}}$ \\
Group C (10\% shoti) & $316.67 \pm 4.00$ & $750.00 \pm 5.00^{\mathrm{a}}$ & $1150.00 \pm 10.00^{\mathrm{a}}$ & $1416.67 \pm 16.00^{\mathrm{a}}$ \\
Group D (15\% shoti) & $313.33 \pm 3.33$ & $673.33 \pm 3.33^{\mathrm{c}}$ & $1050.00 \pm 10.00^{\mathrm{c}}$ & $1240.00 \pm 5.00^{\mathrm{c}}$ \\
\hline
\end{tabular}




\section{J. Alam and others}

Table 2. Hematological and biochemical values (Mean \pm SE) of different groups of broilers $(n=5)$ after feeding different level of shoti at day 38. Values with different letter in a column differ significantly $(\mathrm{p}<0.05)$.

\begin{tabular}{llllllll}
\hline Groups & $\begin{array}{l}\text { TEC } \\
(\text { Million/mm3) }\end{array}$ & Hb $(\mathrm{gm} \%)$ & $\begin{array}{l}\text { ESR(mm } \\
\text { first hour })\end{array}$ & AST (U/L) & ALT (U/L) & $\begin{array}{l}\text { Uric Acid } \\
(\mathrm{mg} / \mathrm{dl})\end{array}$ & $\begin{array}{l}\text { Creatinine } \\
(\mathrm{mg} / \mathrm{dl})\end{array}$ \\
\hline Group A & $2.00 . \pm 0.09^{\mathrm{a}}$ & $6.07 \pm 0.12^{\mathrm{a}}$ & $4.67 \pm 0.58^{\mathrm{b}}$ & $19.79 \pm 2.67^{\mathrm{a}}$ & $19.40 \pm 6.79^{\mathrm{a}}$ & $5.20 \pm 0.10$ & $0.60 \pm 0.11^{\mathrm{a}}$ \\
Group B & $2.20 \pm 0.10^{\mathrm{ab}}$ & $6.67 \pm 0.46^{\mathrm{ab}}$ & $7.67 \pm 0.25^{\mathrm{ab}}$ & $31.08 \pm 6.61^{\mathrm{b}}$ & $10.67 \pm 3.20^{\mathrm{b}}$ & $4.89 \pm 0.96$ & $0.67 \pm 0.12^{\mathrm{a}}$ \\
Group C & $2.38 . \pm 0.03^{\mathrm{ab}}$ & $6.80 \pm 0.40^{\mathrm{ab}}$ & $7.00 \pm 0.50^{\mathrm{b}}$ & $34.58 \pm 3.35^{\mathrm{c}}$ & $11.83 \pm 4.94^{\mathrm{b}}$ & $5.95 \pm 2.21$ & $0.82 \pm 0.53^{\mathrm{b}}$ \\
Group D & $2.47 \pm 0.06^{\mathrm{b}}$ & $6.84 \pm 0.31^{\mathrm{b}}$ & $7.47 \pm 1.00^{\mathrm{a}}$ & $36.43 \pm 8.05^{\mathrm{b}}$ & $12.42 \pm 3.00^{\mathrm{b}}$ & $5.59 \pm 6.62$ & $0.89 \pm 0.78^{\mathrm{b}}$ \\
\hline
\end{tabular}

On day 38 significantly ( $<<0.05$ ) higher weight gain was recorded in group C compare to group B and group D. All that groups differ significantly $(\mathrm{p}<0.05)$. The increased body weight might be due to increase feed consumption and efficiency of feed utilization which is essential for their health and body weight gain. Shoti meal had a more drastic effect on body weight of broiler. Food intake recorded for high shoti meal that simple starvation might have explained the loss of body weight. The findings of present study is similar to Latif et al. (1979) and Rahman (2012) who found that food intake and growth rate of broilers feeding high percentage of shoti meal were significantly $(\mathrm{p}<0.05)$ lower than those of control group. Cross $(1978)$ described that due to presence of high ash content $9.85 \%$ in shoti feed is diluted and birds tend to eat less. On the final day of experiment (38 days of age) the total erythrocyte count (TEC) in group A (control) was 2.00. \pm 0 . 09 million/ $\mathrm{mm}^{3}$, group B (shoti $5 \%$ ) was $2.20 \pm 0.10$ million $/ \mathrm{mm}^{3}$, group C (shoti $10 \%$ ) was $2.38 \pm 0.03 \mathrm{million} / \mathrm{mm}$ and group D (shoti $15 \%$ ) was $2.47 \pm 0.06$ million/ $\mathrm{mm}^{3}$. The highest total erythrocyte count (TEC) was recorded in group D and lowest in group A (Table 2). Significant $(\mathrm{p}<0.05)$ differences were observed among the treated groups compared to control group. The total erythrocyte count (TEC) in group A varied significantly $(p<0.05)$ from all other groups. But difference among the groups B, C and D were insignificant $(p>0.05)$. The hemoglobin $(\mathrm{Hb})$ content in group A (control) was $6.07 \pm 0.12 \mathrm{gm} / \mathrm{dl}$ and group B (shoti $5 \%$ ) was $6.67 \pm 0.46 \mathrm{gm} / \mathrm{dl}$, group C (shoti $10 \%$ ) was $6.80 \pm 0.40 \mathrm{gm} / \mathrm{dl}$ and group D (shoti $15 \%$ ) was $6.84 \pm 0.31 \mathrm{gm} / \mathrm{dl}$. The highest hemoglobin content was recorded in group D (Shoti 15\%) and lowest in group A (Control). Significant $(\mathrm{p}<0.05)$ differences were observed among the groups compared to control group. The differences among groups B, C and D in shoti treated groups were insignificant $(\mathrm{p}>0.05)$. Erythrocyte sedimentation rate of group A, B, C, and D were $4.67 \pm 0.58,7.67 \pm 0.25,7.00 \pm 0.50,7.47 \pm 1.00 \mathrm{~mm}$ in first hour respectively. The highest ESR was in group D (shoti 15) and lowest was in group A (control) and group C (shoti 10\%). The AST level was $19.79 \pm 2.67 \mathrm{u} / \mathrm{l}$ in control group (group A). In the treated groups the value were $31.08 \pm 6.61 \mathrm{u} / 1,34.58 \pm 3.35 \mathrm{u} / \mathrm{l}$ and $36.43 \pm 8.05 \mathrm{u} / \mathrm{l}$ in group B, C and D respectively. Within the treated groups $15 \%$ shoti, (GroupD) is significantly $(\mathrm{p}<0.05)$ higher to that of 5\% shoti (group B), and 10\% shoti (Group C). The ALT value in control (Group A) was 19.40 \pm 6.79 $\mathrm{u} / \mathrm{l}$. Within the treated groups $10.67 \pm 3.20 \mathrm{u} / \mathrm{l}$ in $5 \%$ shoti (Group B), $11.83 \pm 4.94 \mathrm{u} / 1$ in $10 \%$ shoti (Group C), and $12.42 \pm 8.00 \mathrm{u} / \mathrm{l}$ in $15 \%$ shoti (group D). The ALT value in group A is significantly higher $(\mathrm{p}<0.05)$ than the other groups. This is the first report in broiler fed shoti. However, Amubode and Fetuga (1984) stated that AST was not affected by higher dietary protein supplementation and ALT was decreased in the plasma with increased protein level. Kumar and Ruwat (1976) observed that the AST and ALT concentration in blood serum decrease with advancement of age. Swain and Johri (2000) observed that increase level of selenium and vitamin decrease the level of AST and ALT in serum. Huff et al. (1992) reported that supplementation of vitamin decrease AST and ALT level. Chandra et al. (1984) reported that AST activity increases with the supplementation of urea in feed. The uric acid concentration was $5.20 \pm 0.10 \mathrm{mg} / \mathrm{dl}$ in control group (group A). In the treated groups the value were $4.89 \pm 0.96 \mathrm{mg} / \mathrm{dl}, 5.95 \pm 2.21 \mathrm{mg} / \mathrm{dl}, 5.59 \pm 6.62 \mathrm{mg} / \mathrm{dl}$ in group B, C and D respectively. Within the treated groups, group C $(10 \%$ shoti) showed significantly higher uric acid concentration $(\mathrm{p}<0.05)$ than the group B $(5 \%$ shoti) and group D (15\% shoti) but group B and group D did not differ significantly $(\mathrm{p}<0.05)$. This increased in uric acid might be due to excess deamination of protein. The present study differs to that of Machín et al. (2004) who recorded that high protein diet increases the plasma uric acid concentration. The creatinine concentration was $0.60 \pm 0.11 \mathrm{mg} / \mathrm{dl}$ in control group (group A). In the treated groups the value were $0.67 \pm 0.12 \mathrm{mg} / \mathrm{dl}, 0.82 \pm$ $0.53 \mathrm{mg} / \mathrm{dl}, 0.89 \pm 0.78 \mathrm{mg} / \mathrm{dl}$ in group $\mathrm{B}(5 \%$ shoti), group C (10\% shoti) and group D (15\% shoti) respectively. Lowest value was recorded in group $\mathrm{A}$ and is significantly $(\mathrm{P}<0.05)$ higher to other groups. This is the first report 
in broiler fed shoti. However, Swain and Johri (2000) detected that uric acid level increased significantly $(\mathrm{p}<0.05)$ with probiotics supplementation. Kumar and Ruwat (1976) showed that the uric acid concentration in blood serum increased with advancement of age. Huff et al. (1992) also reported that supplementation of probiotics increased uric acid and creatinine. Itoh et al. (1995) observed little variation in uric acid level with regard to age, sex or breed.

\section{REFERENCES}

1. Aggarwal BB, Sundaram C, Malani N and Ichikawa H (2007). Curcumin Indian solid gold. Medical Biology 595: 697-705.

2. Ali SM, Sitesh C and Islam MS (2004). Analgesic Activity of the Rhizomes of Curcuma zedoaria, Dhaka University. Journal of Pharmacological Science 3: 1-2.

3. Amubode FO and Fetuga BL (1984). The influence of dietary methionine, protein and energy levels on glutamic oxalalactate and glutamic pyruvate transaninases of chicken. Beitr Trop Landwirtsch Veterinary Medical 22: 193200.

4. Chandra M, Singh B, Soni GL and Ahuja SP (1984). Renal and biochemical changes produced in broilers by high protein, high calcium urea containing, and vitamin A defecint diets. Avian Diseases 28: 1-11.

5. Cross DL (1978). Efficacy of broiler litter silage for beef steers. Journal of Animal Science 47: 544.

6. Gomez KA and Gomez AA (1984). Duncan's multiple Range test. Statistical Procedures for Agricultural Research. Second edition. John Wiley and Sons. 207-215.

7. Huff ML, Nakaue HS and Mirosh LW (1992). Effect of probiotics on performance and biochemical parameters in pullet. Journal of Poultry Science 43: 296-300.

8. Islam MA, Kloppstech K and Esch E (2005). Population genetic diversity of Curcuma zedoaria roscoe- a conservation prioritized medicinal plant in Bangladesh. Conservation Genetics 6: 1027-1033.

9. Itoh N, Moritus Yand and Ichikawa S (1995). Comparison of blood chemical value of Japanese quail, white leghorn and broiler chicken. Journal of Veterinary Medicine 48: 97-110.

10. Kumar JS and Ruwat (1976). Effect of mineral on growth performance and biochemical parameters. Indian Journal of Animal Science 45: 135-138.

11. Lamberg SL and Rothstein R (1977). Laboratory manual of hematology and urinalysis. Avi Publishing Company, Inc. Wesport Connecticent, U.S.A.

12. Latif MA, Morris TR, Miah AH, Hewitt D and Ford JE (1979). Toxicity of shoti (Indian arrowroot: Curcuma zedoaria) for rats and chicks. British Journal of Nutrition 41: 57-63.

13. Machín M, Simoyi MF, Blemings KP and Klandorf H (2004). Increased dietary protein elevates plasma uric acid and is associated with decreased oxidative stress in rapidly-growing broilers. Comparative Biochemistry and Physiology Part B Biochemistry and Molecular Biology 137: 383-90.

14. Rahman S (2012). Chemical and nutrition evaluation of Curcuma zedoaria (shoti) on the performance of broiler production. MS thesis, Department of plant pathology, Bangladesh Agricultural University, Mymensingh.

15. Rashid ABD and Yuhasliza N (2004). Chemical constituents and biological activities of curucma xanthorrhiza and curcuma heyneana (Doctoral dissertation, School of Graduate Studies, Universiti Putra Malaysia).

16. Swain and Johri (2000). Effect of probiotics (Saccharomyces cerevisiae) on growth performance and hematobiochemical parameters of broiler chicks. International Journal of Poultry Science 2: 142-148.

17. Tipthara P, Sangvanich P, Macth M and Petsom A (2007). Mannose-binding lectin from Curcuma zedoaria rosc. Journal of Plant Biology 50: 167-173. 